\title{
Exploring Learning Through Cognitive Constructivism: The Case for Online Lessons
}

Memiyanty Abdul Rahim, Azizan Zainuddin, Mazlan Che Soh, Farhatul Mustamirrah Mahamad Aziz, Nor Syadza Izzati Muhamad Sharif, Noor Hanim Rahmat

To Link this Article: http://dx.doi.org/10.6007/IJARBSS/v11-i12/11505 DOI:10.6007/IJARBSS/v11-i12/11505

Received: 03 October 2021, Revised: 07 November 2021, Accepted: 27 November 2021

Published Online: 16 December 2021

In-Text Citation: (Rahim et al., 2021)

To Cite this Article: Rahim, M. A., Zainuddin, A., Soh, M. C., Aziz, F. M. M., Sharif, N. S. I. M., \& Rahmat, N. H. (2021). Exploring Learning Through Cognitive Constructivism: The Case for Online Lessons. International Journal of Academic Research in Business and Social Sciences, 11(12), 1859-1873.

\section{Copyright: (c) 2021 The Author(s)}

Published by Human Resource Management Academic Research Society (www.hrmars.com) This article is published under the Creative Commons Attribution (CC BY 4.0) license. Anyone may reproduce, distribute, translate and create derivative works of this article (for both commercial and non0-commercial purposes), subject to full attribution to the original publication and authors. The full terms of this license may be seen at: http://creativecommons.org/licences/by/4.0/legalcode

$$
\text { Vol. 11, No. 12, 2021, Pg. } 1859 \text { - } 1873
$$

Full Terms \& Conditions of access and use can be found at http://hrmars.com/index.php/pages/detail/publication-ethics 


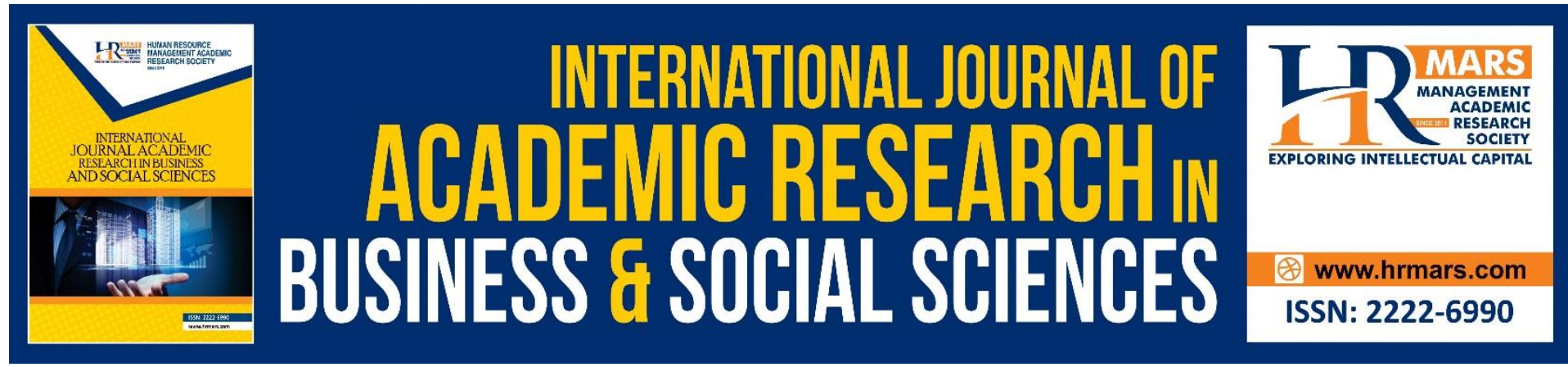

\title{
Exploring Learning Through Cognitive Constructivism: The Case for Online Lessons
}

\author{
Memiyanty Abdul Rahim ${ }^{1}$, Azizan Zainuddin², Mazlan Che \\ Soh $^{3}$, Farhatul Mustamirrah Mahamad Aziz ${ }^{4}$, Nor Syadza Izzati \\ Muhamad Sharif ${ }^{5}$, Noor Hanim Rahmat ${ }^{6}$ \\ ${ }^{1-5}$ Faculty of Administrative Science \& Policy Studies, ${ }^{6}$ Faculty of Education \\ Universiti Teknologi MARA, Shah Alam, Selangor \\ Corresponding author: memiyanty@uitm.edu.my
}

\begin{abstract}
Online learning continues to rise and become popular as COVID-19 pandemic has attacked at the end of 2019, it is found that many colleges and universities are required in introducing this approach in the class. Previous studies showed that those students involved in online learning were less likely to engage in collaborative learning, student-faculty reactions, and discussions with diverse others, compared to their more traditional classroom. The students with greater numbers of online courses also reported less exposure to effective teaching practices and lower quality in interactions. Indeed, this online learning imposes certain limitations and requires continuous strategy and momentum to ensure active and authentic learning. The objective of this study is to examine the engagement of students from online learning. This study examined how online learning can affect learner participation in their learning process: engagement, learner to instructor engagement and learner to content engagement. 75 learners participated in this quantitative research. The survey is adapted from Martin and Bolliger (2018) and there are 14 items excluding the demographic profiles. The items are categorised into: Learner-to-learner engagement (6 items); Learner-toInstructor Engagement ( 7 items); and (3) Learner-to-content Engagement ( 7 items). Data is analysed using SPSS version 26 to reveal the frequency of responses. Findings revealed that learners are highly active and authentic learners during the class. These findings have interesting online learning ramifications towards university students.
\end{abstract}

Keywords: Online Learning, Engagement, Learner, Instructor, University

\section{Introduction}

\section{Background of Study}

The origin of the e-learning term is less clear although many definitions and opinions have been debated about it around the 1980s. Most scholars give a vague or equate e-learning definition and put it under the same themes such as online courses or learning, web-based learning and so on. The online learning described by most scholars is more of an access to learning experiences using technology. While other scholars mentioned the definition of online learning as the latest version of distance learning that has improved access to a wider 
range of educational opportunities (Moore, Deane \& Galyen, 2010). Smart and Cappel (2006), define e-learning as instructions delivered electronically via the Internet, Intranet or other multimedia platforms such as CD-ROM or DVD. Online learning is becoming very popular because of its potential to provide flexible access and can be used at any time (Picciano et al., 2012). However, as a result of the rapid and dynamic development of technology, there are variations on the applications used to support various forms of online learning that may create a challenge especially to the students.

There are various issues that have been highlighted when it comes to online learning. Firstly is to adapt with the new way of learning. Switching from the traditional classroom to virtual classroom leads to a different learning experience for each student. Students who have a traditional mindset will find it difficult to accept a new way of learning. Besides that, the issues of computer literacy among students are another big challenge where most of the students cannot operate a basic program such as Microsoft Word or PowerPoint and therefore are unable to handle their files (Barrot et al., 2021). The situations make the learner struggle to cope with the e-learning environment. Previous studies have also shown that e learning leads to the feelings of frustration, anxiety and confusion among students. In fact, the dropout rate has also increased (Smart and Cappel, 2006).

\section{Statement of Problem}

As the popularity of online learning continues to rise and become popular, it is found that many colleges and universities are interested in introducing this approach in the class. This is based on the premise that online learning contributes quite a number of advantages. Dumford and Miller (2018) in their studies to explore the ways in which taking courses through an online medium impacts student engagement, utilizing data from the National Survey of Student Engagement. The results from these studies indicated numerous significant relationships between taking online courses and student engagement either for both first year students and seniors. Among the advantages found from these studies is that those students taking a greater number of online courses were more likely to engage in quantitative reasoning. In more recent studies, Mukhtar et al (2020) in their studies on online learning during pandemic Covid-19 in Pakistan found that among the advantages of online learning were remote learning, comfort, and accessibility. Fatonia et al (2020) research on these issues from the perspective of Indonesian students during Covid-19 pandemic. From their studies they found that among the advantages of online learning were that the students feel with this kind of method they can listen at home and they are not limited by the place, in which they can listen anytime anywhere, and they are not limited by time or space.

Online learning no doubt contributes to some problems. Again, from Dumford and Miller (2018), they found that those students involved were less likely to engage in collaborative learning, student-faculty reactions, and discussions with diverse others, compared to their more traditional classroom in such learning also past studies on problems with online learning. The students with greater numbers of online courses also reported less exposure to effective teaching practices and lower quality in interactions. Mukhtar et al. (2020) in their studies found that among the limitations in online learning were inefficiency and difficulty in maintaining academic integrity. Fatonia et al (2020) also found that among the advantages of online learning faced by the Indonesians students were network instability in which the delays often occur, teacher's voices and teaching materials are not synchronous, 
they cannot take classes when wi-fi is not connected. Another problem faced by students in Indonesia in online learning were unilateral interaction and reduced concentration.

Hence, this study is done to explore interactions during online learning. Specifically, this study is done to answer the following research questions;

- RQ1-How is active learning done for learners?

- RQ2-How is active learning done by instructors?

- RQ3- How is authentic learning done through the content?

\section{Literature Review Introduction}

This section discusses issues of active learning online, authentic learning, past studies; as well as, the conceptual framework of the study.

\section{Active Learning Online}

It is essential to understand factors that contributed to active learning in online class. Findings indicated that online learner participation and patterns of participation were influenced by the following factors: technology and interface characteristics, content-area experience, student roles and instructional tasks, and information overload and there may be a reciprocal relationship among these factors (Vonderwell \& Zachariah, 2005). Moore (1993) identified three types of interaction inherent in effective online courses: (1) learner-to-learner interaction, (2) learner-to-instructor interaction, and (3) learner-to-content interaction. Meanwhile, Anderson (2003) emphasizes a simpler explanation on active learning online in which student engagement is developed through interaction. Interaction and engagement are indeed closely related and even used interchangeably.

Chickering and Gramson (1987) proposed a framework to ensure students' engagement: "Seven Principles for Good Practice in Undergraduate Education." The seven principles identified in this framework list that students are more engaged when the instruction (1) increases the contact between student and faculty, (2) provides opportunities for students to work in cooperation, (3) encourages students to use active learning strategies, (4) provides timely feedback on students' academic progression, (5) requires students to spend quality time on academic tasks, (6) establishes high standards for acceptable academic work, and (7) addresses different learner needs in the learning process. Online learning imposes certain limitations and requires continuous momentum to ensure active learning. The study done in 1987 on students' engagement may have been proposed for the face-toface class but with current technology development all of these interactions can be done in the real time thus ensuring continuous momentum. 


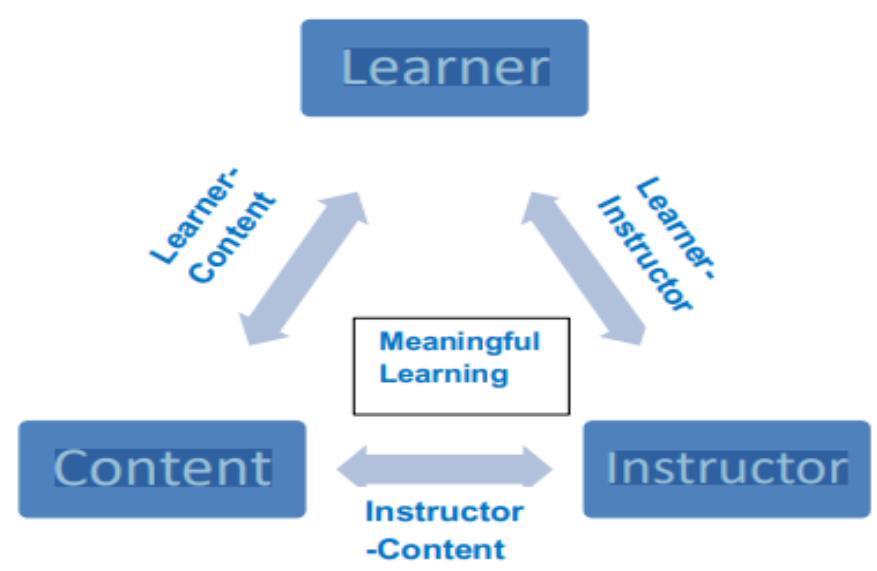

Figure 1- Types of Interaction based on Moore's Framework

(Source: Moore et. al, 2010)

Based on Moore's framework (Figure 1), Hillman, Willis, and Gunawardena (1994) stated that new technologies create a fourth type of interaction that is learner interface interaction. Learner interface interaction is defined as the interaction that takes place between a student and the technology used to mediate a particular distance education process. Such interaction emphasizes on a real time interaction despite how far the distance is and without interruption. From the figure by Moore, it realizes the meaningful learning on the content of learning by the instructor. Instructors can utilize multiple-threaded discussions instead of single-threaded linear discussions when appropriate for the content and learners (Vonderwell and Zachariah, 2005)

Learner-to-learner interaction is extremely valuable for online learning and leads to student engagement. To prevent online students from experiencing potential boredom and isolation in the learning environment, it is essential to build activities that enhance engagement (Vonderwell and Zachariah, 2005). Even in the face-to-face class students can feel isolated due to lack of interaction, it is more so in the online learning situation. Continuous engagement ensures active participation be it face-to-face or online learning.

Learner-to-instructor interaction leads to higher student engagement in online courses (Dixson, 2010; Gayton \& McEwen, 2007). The use of multiple student-instructor communication channels may be highly related to student engagement. It is recommended that online instructors pay special attention to student-instructor interactions because they may affect learning outcomes (Dixson, 2010; Gayton \& McEwen, 2007). Gayton and McEwen (2007) stress that instructors' presence in online courses is required in terms of actively involving students in their courses; however, online instructors should be minimally active in discussions when online courses are purposefully designed so that the more students engage, the more meaningful learning outcomes will be.

\section{Authentic Learning Online}

The notion of authentic learning is more of a philosophy, useful as a model for curriculum method rather than as a learning theory (Herrington, 2014). It grew out of a structure of work that sought to understand learning in workplace apprenticeships. Brown, Collins, and Duguid (1989) expressed 'situated cognition' in an attempt to reunite a 'breach between learning and use ...' or the 'know what' and 'know how' of a practice or profession (Brown et al., 1989). 
Situated cognition is the idea that knowledge is almost always structured by context and progressively developed by use (Brown et al., 1989).

Here the term authentic learning is used in its most general sense in which learning is supported by being situated in an environment that aligns learning objectives with real-world tasks, content and context. To add, authentic learning methods have been seen as a new technique to act as a medium from instructor to learner for the transmission of knowledge to the real-world implementation. But how would education facilitate authentic learning through online? According to (Herrington, 2014) to implement the method, technologies are required as it is associated with technology-based learning where it is suitable for online learning. For instance, new web-based technologies and mobile devices accommodate the needs for online learning as both cognitive tools and delivery platforms as it would relay the authentic learning experiences in education to the students and therefore improving the perception of the context regarding the real-world tasks. Without a doubt, technology does play an important role for online learning.

\section{Past Studies}

\section{Disadvantages of Learning Online}

What would cause the students feeling disengagement when online learning is that they feel alienated and isolated from their classmates as well as less interaction by the lecturer. The study by Kear (2010) was done to investigate the social presence in online learning communities and the instrument used was interviews carried out with students at the UK Open University. These interviews aimed to explore students' experiences of using online communication in a distance learning course, and their ideas for improvements to online communication systems for learning. The interviews revealed problems, such as poor communication and misunderstandings, associated with a lack of social presence. Students highlighted system features that they found useful, or would like to have available, which would help to address these issues. In particular, they suggested that increased use of member profiles would help them get to know each other better, and that synchronous communication tools such as instant messaging would be of practical and social value. Another study also by Capra (2011), was done to investigate the Promise and Problem within Online Education and the instrument used was a variation of the Technology Acceptance Model (TAM, developed by Davis in 1989) to measure student satisfaction with web-based instruction in university level business courses. They highlighted a strong relationship between satisfaction with the instructor and satisfaction with the course. A final conclusion was postulated that as online education and its variations expand, the significance of the course instructor should not be overlooked. This finding is parallel to other studies that underscore the pivotal role of the instructor in distance education courses (Morris, 2009; Eom et al., 2006). Although the instrument used was different, the final conclusion is about satisfaction on online learning regarding students.

\section{Advantages of Learning Online}

Online learning has changed the traditional and natural way of learning, to a more structured and technical approach to learning. Thus, constraints such as the limited quality of normal interaction compared to traditional ways of learning have led to the positive finding that online learning has offered many benefits. A study conducted by Smart and Cappel (2006) on students' perceptions towards online learning found that the instructions given via online have potential in providing opportunities to enhance the reflective thinking and deep learning 
by applying and integrating the learning elements. In addition, online instruction offers the flexibility and facilitation to complete their learning according to the time and place chosen by the students.

Referring to the flexibility situation, another quantitative study conducted at five private universities in Indonesia found that most students felt that they had the advantage of studying online because of the flexible environment that they could study without time and place constraints. In fact, the findings of the study also show that students do not have to face the cost and long travel time to get to the class. The study showed that students were more comfortable to interact and ask questions via online during the class (Agus, 2020). The study also found that the higher the students' experience in technology the higher level of students' learning satisfaction in using the new technology.

\section{Conceptual Framework}

This study (Figure 2) is rooted from Piaget's (1971) cognitive constructivism. The two main principles of learning are (a) active learning; (b) authentic learning. Piaget (1971) states that learners learn best when they are actively participating in the learning. This can be challenging in online classes, but not impossible. Next, Piaget (1971) also states learners need to appreciate the knowledge as authentic and real. According to Rahmat, et.al (2021) learning can be real through engagement in the online environment. The two principles of cognitive constructivism are scaffolded onto Martin and Bollinger's (2018) online engagement to explain how online learning can be both active and authentic.

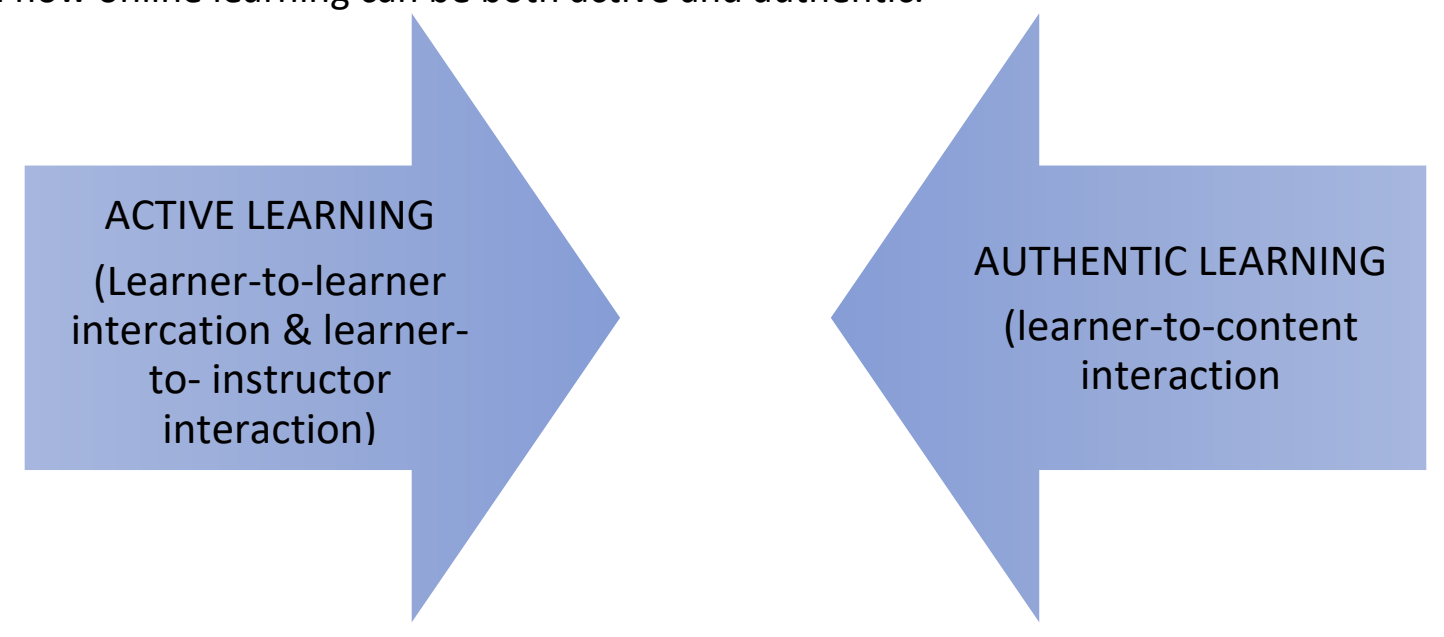

Figure 2- Conceptual Framework of the Study-Active and Authentic Learning in ODL

\section{Methodology}

This quantitative study is done to investigate how learners are affected by online learning. 75 respondents were purposely chosen from learners at the undergraduate and postgraduate level. They attended the course that involved theory and computation (public and corporate finance) via online learning (Undergraduate and Postgraduate students) at the Faculty of Administrative Science and Policy Studies, Universiti Teknologi MARA, Malaysia. The instrument (refer to Table 1) used was a questionnaire adapted from Martin and Bolliger (2018). The 24 items were asked using a 5-Likert scale survey via google form online. 
Table-1. Distribution of Items in Instrument

\begin{tabular}{|l|l|l|l|}
\hline Construct & Section & & No of Items \\
\hline & $\mathrm{A}$ & Demographic Profile & 4 \\
\hline $\begin{array}{l}\text { Online Learning and } \\
\text { Engagement } \\
\begin{array}{l}\text { Martin and Bolliger } \\
(2018)\end{array}\end{array}$ & $\mathrm{B}$ & $\begin{array}{l}\text { Learner--to-learner } \\
\text { Engagement }\end{array}$ & 6 \\
\cline { 2 - 4 } & $\mathrm{C}$ & $\begin{array}{l}\text { Learner-to-Instructor } \\
\text { Engagement }\end{array}$ & 7 \\
\cline { 2 - 4 } & $\mathrm{D}$ & $\begin{array}{l}\text { Learner-to-content } \\
\text { Engagement }\end{array}$ & 7 \\
\hline
\end{tabular}

Table 1 shows the distribution of items in the survey. The survey is adapted from Martin and Bolliger (2018) and there are 14 items excluding the demographic profiles. The items are categorised into (1) Learner-to-learner engagement (6 items) (2) Learner-to- Instructor Engagement ( 7 items) and (3) Learner-to-content Engagement ( 7 items). Data is analysed using SPSS version 26 to reveal the frequency of responses. Findings are calculated using percentages and mean scores and presented in table respectively. Reliability statistics (shown in Table 2) were carried out to the instrument revealing a Cronbach alpha of 0.761 thus showing a high internal reliability.

Table 2: Reliability Statistics for Instrument

\section{Reliability Statistics}

\begin{tabular}{r|r}
$\begin{array}{c}\text { Cronbach's } \\
\text { Alpha }\end{array}$ & N of Items \\
\hline .761 & 20 \\
\hline
\end{tabular}




\section{Findings}

\section{Findings for Demographic Profile}

75 respondents were involved in the study, the demographic profile can be seen in Figure 3.

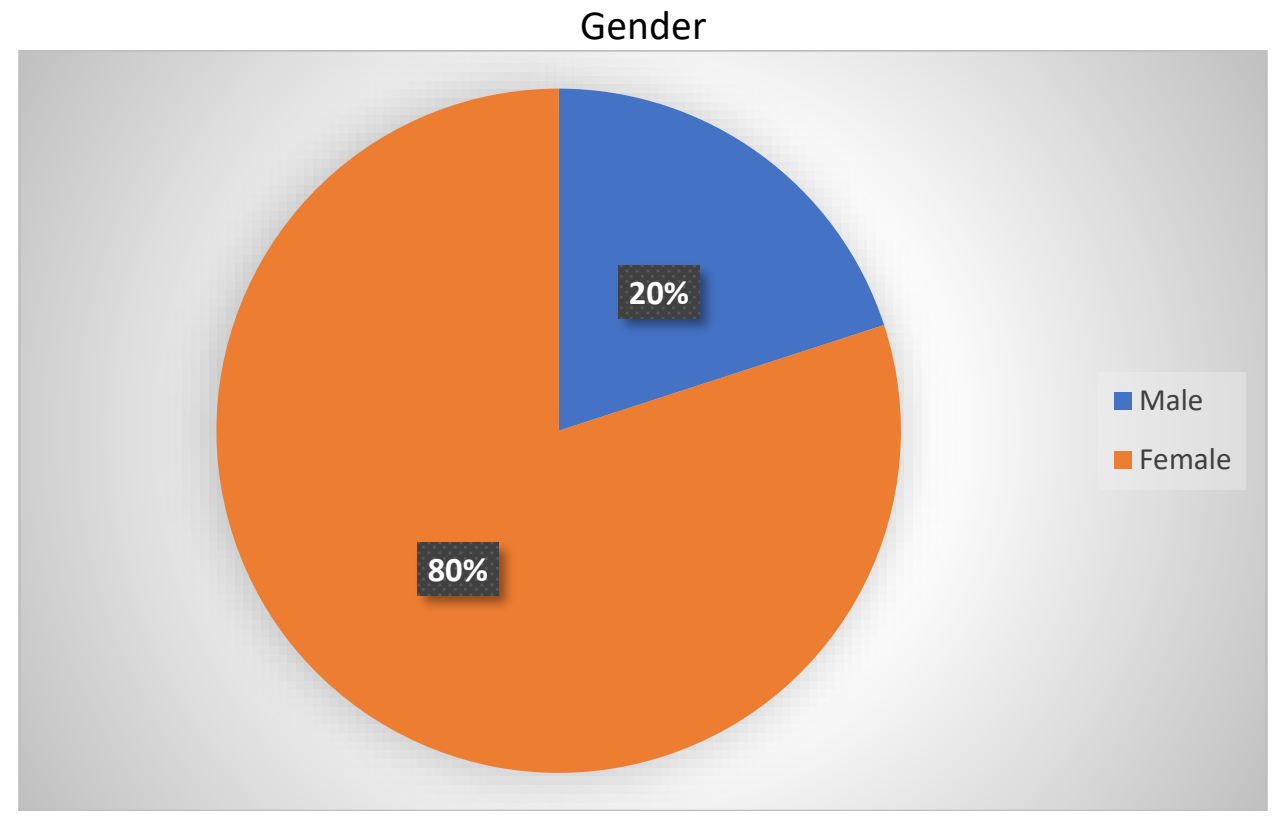

Figure 3 : Percentage for Gender

Based on Figure 3, most of the respondents are female with $80 \%$ which comprise 60 respondents. Meanwhile, 15 out of 75 respondents are male with $20 \%$ of the total respondents.

\section{Age Group}

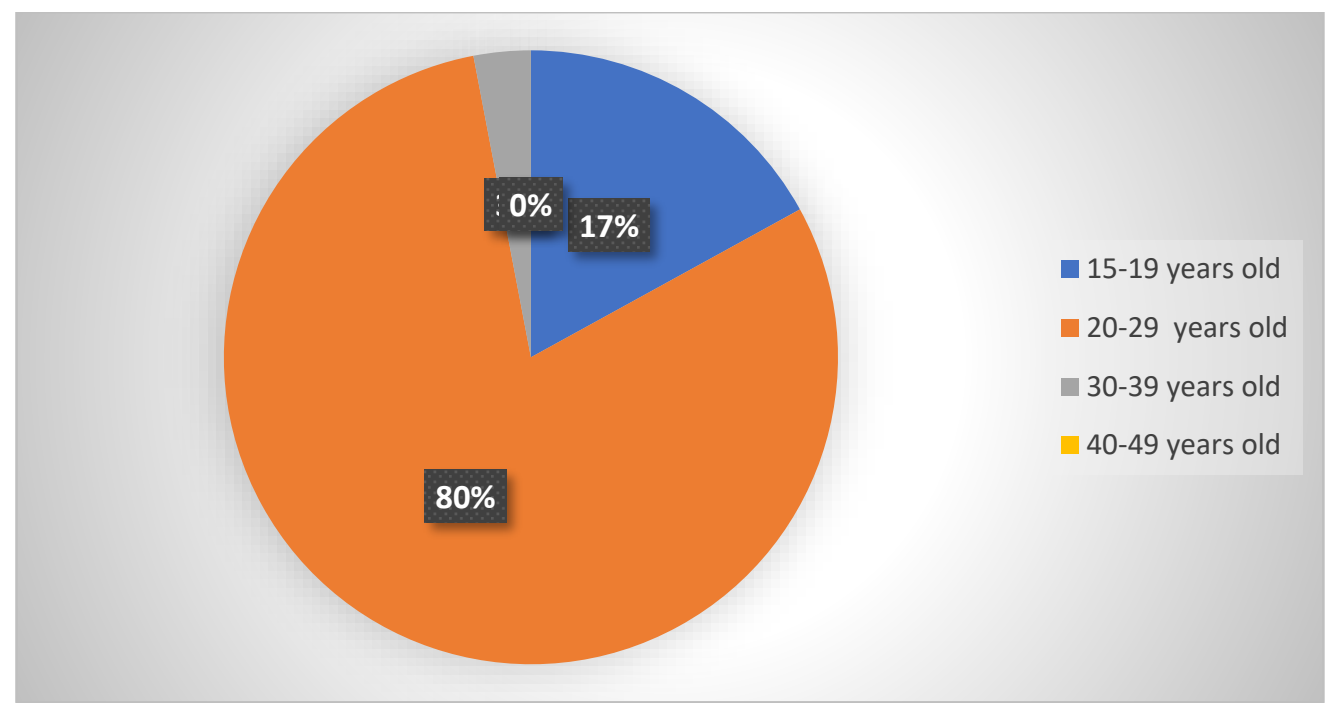

Figure 4: Percentage for Age Group

In figure 4, respondents aged between 20 to 29 years old made up the majority group with a total number of 60 respondents which comprised $80 \%$ while $17 \%$ of the total respondents aged between $15-19$ years old with a total number of 13 respondents. Moreover, 2 out of 75 respondents are $30-39$ years old with $3 \%$ of the total respondents. 
Highest Academic Level

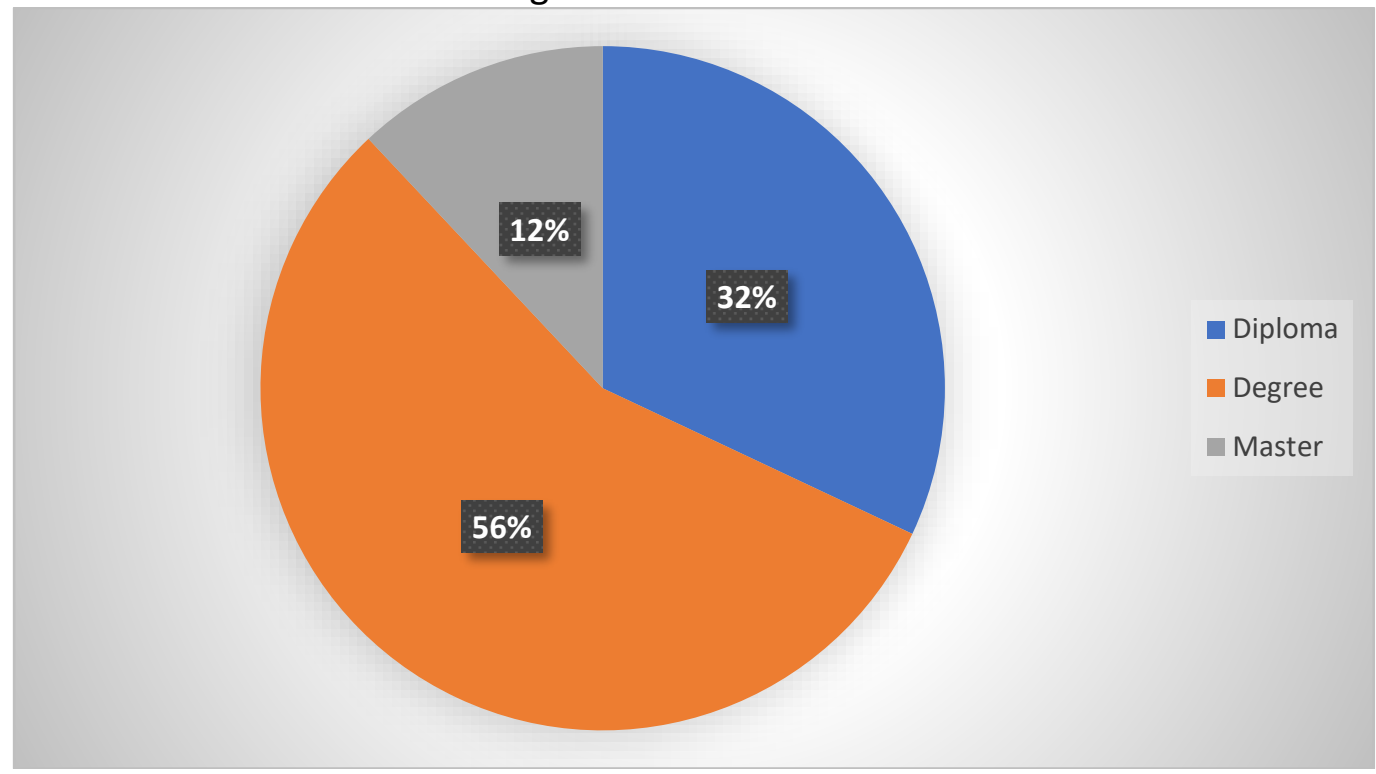

Figure 5: Percentage for Highest Academic Level

Majority of respondents are degree holders with $56 \%$, followed by diploma holders (32\%). Master degree holders are $12 \%$.

\section{Findings Active Learning for Learning}

This section presents data to answer research question 1: How is active learning done for learners? Active learning can be seen through students' interaction in online classes. Figure 6 shows the students' interaction in online classes.

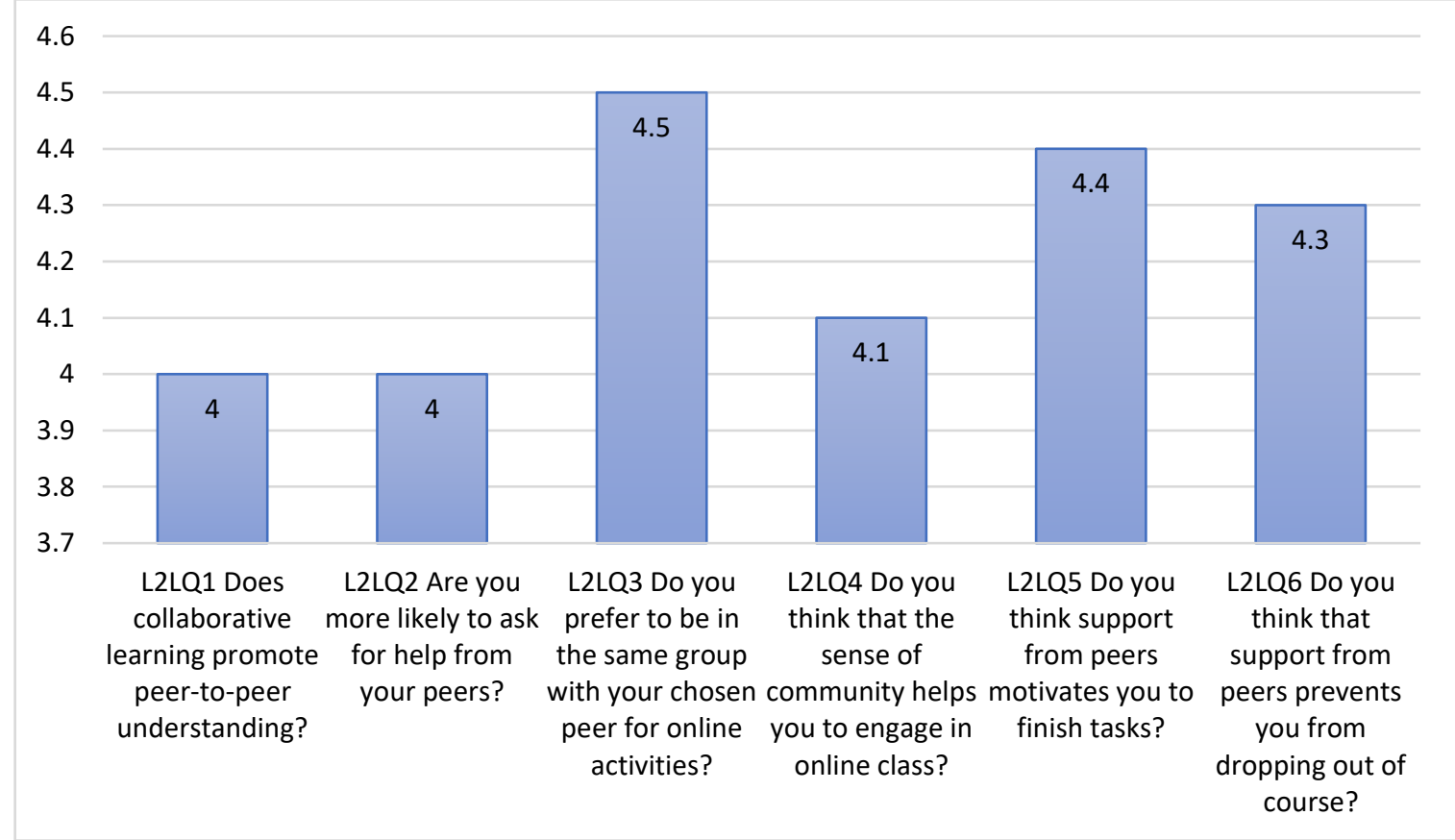

Figure 6- Mean for Students' Interaction

Active Learning is proven as the mean value/score is 4 and higher than 4 . From the findings (Figure 6) that students prefer to be in the same group with their preferred chosen peers for online activities (mean value 4.5). Next, they think support from peers really motivates them 
to finish their work (4.4). In addition, they also think the support from peers may prevent them from dropping out of course (4.3) and even they think the sense of community helps them to engage in online class (4.1). at equal foot of 4 , they agree that collaborative learning promotes peer-to-peer understanding and are likely to ask help from their peers.

\section{Findings for Active learning by Instructors}

This section presents data to answer research question 2: How is active learning done by instructors? Well planned activities by lecturers can lead to active learning in online classes.

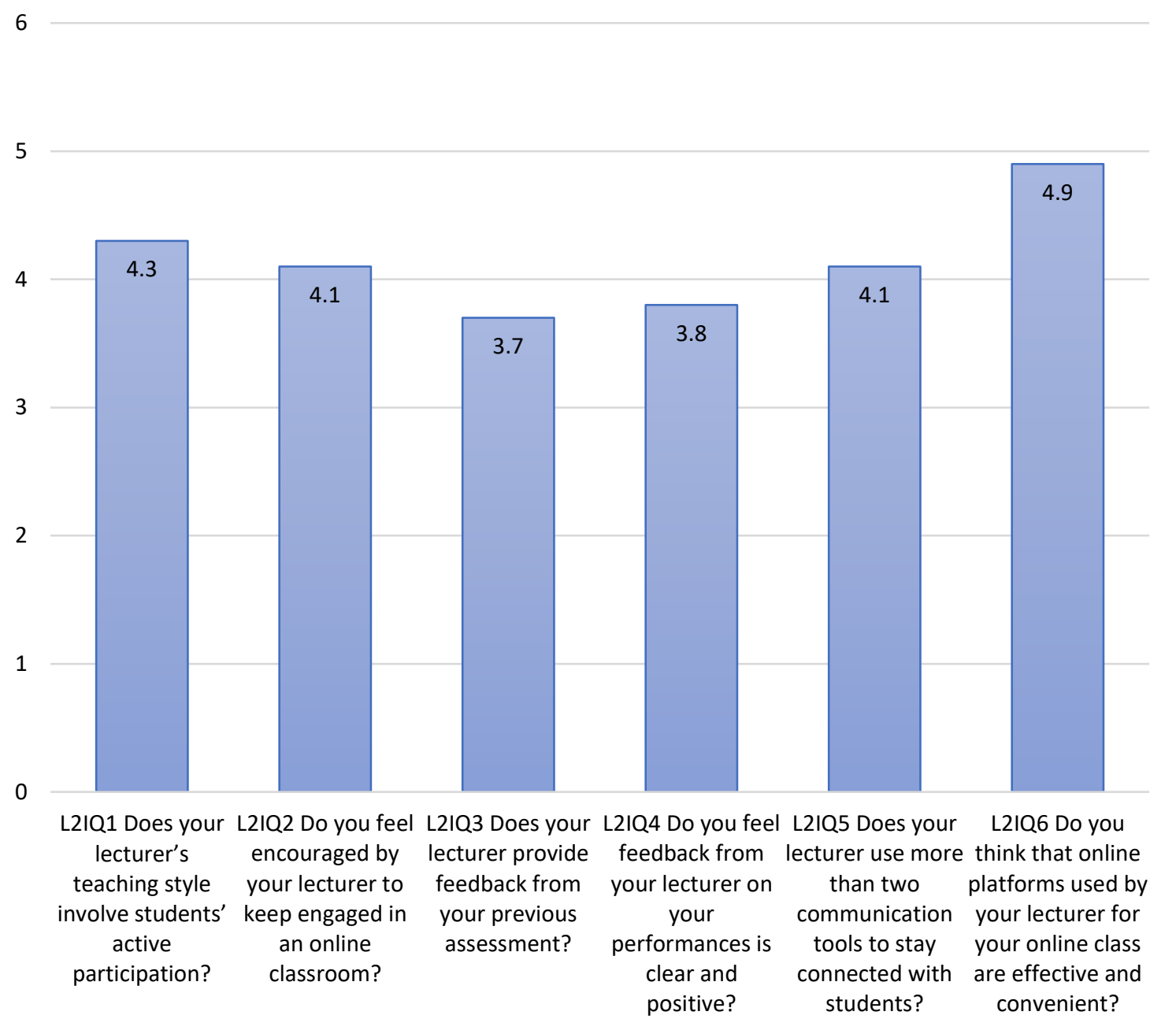

Figure 7- Mean for Students-Lecturer Interaction

Figure 7 shows the mean for students to lecturer interaction in terms of active learning in an online class. The highest mean of 4.9 shows that the students believe the choice of online platforms is crucial in determining the effectiveness of students to lecturer interaction. To add, they agree most of the lecturer's teaching style involves students' active participation (4.3), they feel encouraged by their lecturer to keep engaged in online classrooms (4.1) and they agree their lecturer uses more than two communication tools to stay connected with students (4.1). Interestingly, they also agree that their lecturer maintains ongoing interaction with students after online class (4). There are only two scenarios that need to be highlighted as important but not a serious matter as the mean score is still higher at 3.8 and 3.7. They feel feedback from lecturers are moderately clear and positive (3.8) and they expect lecturers can provide feedback from their previous assessment (3.7). 


\section{Findings for Authentic Learning}

This section presents data to answer research question 3: How is authentic learning done through the content? Authentic learning can be achieved through student-to-content interaction.

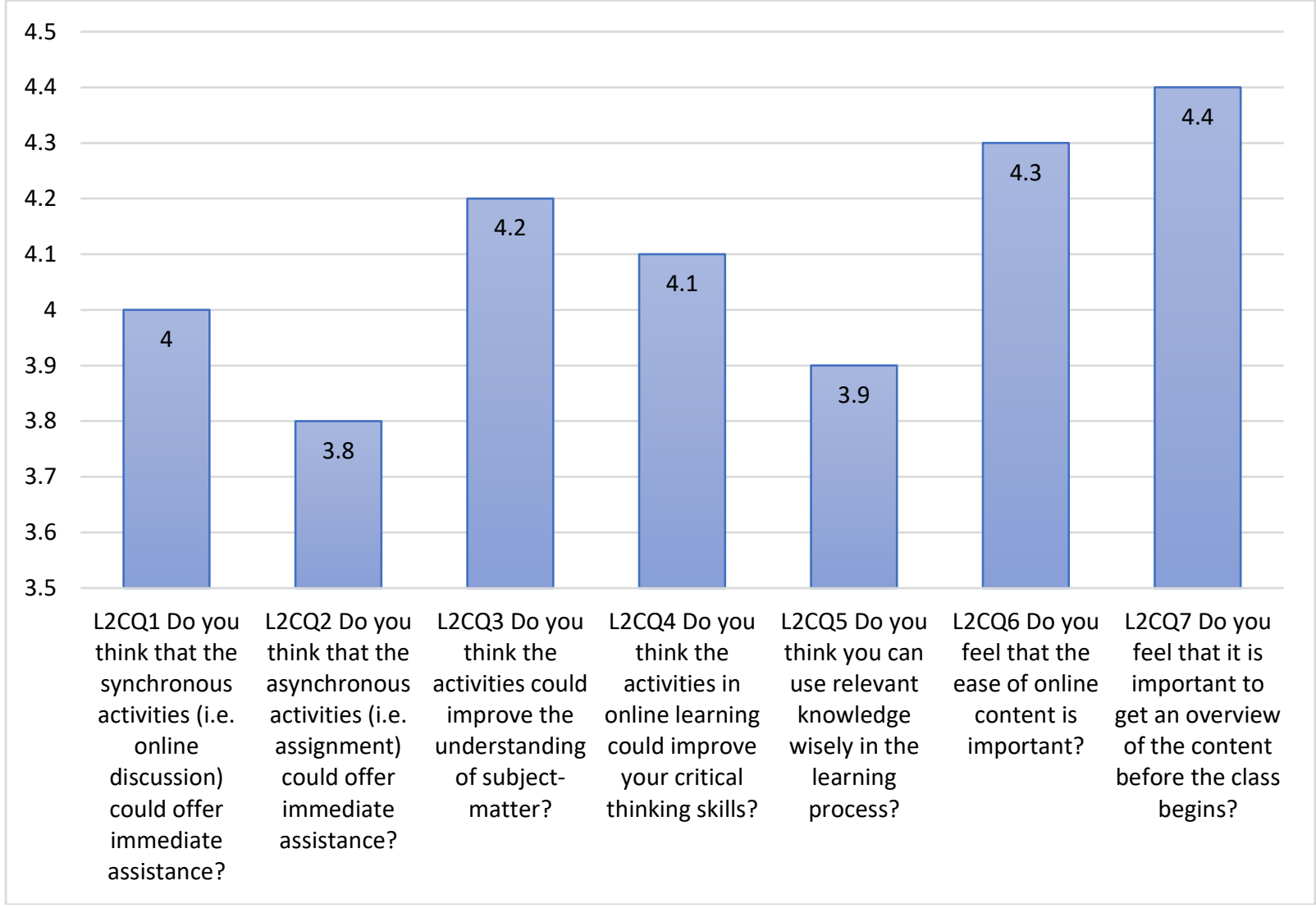

Figure 8-Mean for Authentic learning

Figure 8 shows the mean for Student-to-Content Interaction. As far as the student-content interaction, the respondents believed that it is important for them to get an overview of the content before the class begins (with highest mean 4.4). This follows with their feeling that online content provides them with ease (mean 4.3). The respondents are of the opinion that the activities are among the tools that are needed by them to improve their understanding of subject-matter (mean 4.2) and help to improve their critical thinking skills (mean 4.1). However, the asynchronous activities (i.e. assignment) shows the lowest mean (3.8) in terms of offering immediate assistance. They also think that they can use relevant knowledge wisely in the learning process (3.9).

\section{Conclusion}

\section{Summary of Findings and Discussion}

Based on the findings, it can be concluded that learners being in the same group with their chosen peers, the effectiveness of online platform used by their lecturer and getting an overview of content before class begins has influences learners the most with their participation and engagement in online learning. Overall, the reaction of learners in terms of engagement for each research objective is good. There is no mean value less than 2.5 as an average result for all research objectives. Moreover, the lowest mean value is 3.7 while the 
majority of mean values are above 4. It shows that learners to learners' engagement, learner to instructor engagement and learner to content engagement are very good. Online learning survey that has been conducted via Martin and Bollinger's (2018) model/concept has shown that in Universiti Teknologi MARA for Diploma, Degree and Master's level involving computation subjects has proven successful in gaining engagement from students, lecturers and subject matters.

\section{(Pedagogical) Implications}

The e-learning approach is no longer a new system that only focuses on distance learning or traditional distance education programs. This method of learning has been elevated to another level, as one of the hybrid teaching methods that has been used throughout the world education system. However, the challenge that is expected to have an impact on this teaching force is to integrate this system into the educational environment more systematically and rationally. Significantly, this new educational approach needs to be incorporated into the education system to strengthen existing forms of learning, training and guidance. In fact, Nawar (2017) mentions in his study that only effective and efficient planned online courses can survive to meet the educational needs and can connect them to a wider space through e-learning activities.

5.3 Suggestion for Future Research

Research on the effectiveness and benefits of virtual teaching and learning needs to be implemented more vigorously. This is because this approach is seen to still have a wide gap and requires future research in order to improve the current e- learning method. This study has detailed the point of view of how active learning is made on students and the student's interaction method has been found to be very important in this virtual world classroom. However, so far there has been no study that touches on the effectiveness of online learning towards student achievement. The possibility of future studies should consider looking at those aspects. 


\section{Reference}

Anderson, T. (2004). Teaching in an online learning context. In T. Anderson \& F. Bloumi (Eds.), Theory and practice of online learning (pp. 273-294), Canada: Athabasca University.

Barrot, J. S., Llenares, I. I., \& Rosario, L. S. (2021). Students' online learning challenges during the pandemic and how they cope with them: The case of the Philippines. Education and Information Technologies. 1-18. doi: 10.1007/s10639-021-10589-x.

https://pubmed.ncbi.nlm.nih.gov/34075300/

Capra, T. (2011) Online Education: Promise and Problems. MERLOT Journal of Online Learning and Teaching, Vol. 7, No. 2, June 2011. Retrieved from https://jolt.merlot.org/vol7no2/capra_0611.htm

Chickering, A., \& Gamson, Z. (1987). Seven principles for good practice in undergraduate education. AAHE Bulletin, 39, 3-7. http://dx.doi.org/10.1016/j.iheduc.2004.06.003

Dixson, M. D. (2010). Creating effective student engagement in online courses: What do students find engaging? Journal of the Scholarship of Teaching and Learning, 10(2), 113. https://files.eric.ed.gov/fulltext/EJ890707.pdf

Dumford, A. D., \& Miller, A. L. (2018). Online learning in higher education: exploring advantages and disadvantages for engagement. Journal of Computing in Higher Education, 30(3), 452-465. Available at https://doi.org/10.1007/s12528-018-9179-z

Fatonia, N. A., Nurkhayatic, E., Nurdiawatid, E., Fidziahe, G. P., Adhag, S., Irawanh, A. P., ... \& Azizik, E. (2020). University students online learning system during Covid-19 pandemic: Advantages, constraints and solutions. Systematic Reviews in Pharmacy, 11(7), 570-576. Available at DOI: $10.7777 /$ jiemar.v2i2

Gayton, J., \& McEwen, B. C. (2007). Effective online instructional and assessment strategies. American Journal of Distance Education, 21(3), 117132.doi:10.1080/08923640701341653

Herrington, J., Reeves, T. C., Oliver, R. (2014) Authentic Learning Environments. In: Spector J., Merrill M., Elen J., Bishop M. (eds) Handbook of Research on Educational Communications and Technology. Springer, New York, NY. https://doi.org/10.1007/978-1-4614-3185-5_32

Hillman, D., Willis, D., \& Gunawardena, C. (1994). Learner-interface Interaction in Distance Education: An Extension of Contemporary Models and Strategies for Practitioners. American Journal of Distance Education. Vo. 8, Issue 2. p.30-42. https://doi.org/10.1080/08923649409526853

Kear, K. (2010) Social presence in online learning communities. In: Proceedings of the 7th International Conference on Networked Learning 2010, 3-4 May 2010, Retrieved from http://oro.open.ac.uk/21777/

Martin, F., \& Bolliger, D. U. (2018). Engagement Matters: Student Perceptions on the Importance of Engagement Strategies in the Online Learning Environment. Online Learning, 22(1), 205-222. http://doi.dx/ 10.24059/olj.v22i1.1092.

Moore, J. L., Deane C. D., \& Galyen, K. (2010). e-Learning, online learning, and distance learning environments: Are they the same? Internet and Higher Education. 14(2):129135. doi: 10.1016/j.iheduc.2010.10.001

Moore, M. G. (1989). Three types of interaction. The American Journal of Distance Education, 3(2), 1-6. https://doi.org/10.1080/08923648909526659

Mukhtar, K., Javed, K., Arooj, M., \& Sethi, A. (2020). Advantages, Limitations and Recommendations for online learning during COVID-19 pandemic era. Pakistan journal 
of medical sciences, 36(COVID19-S4), S27. Available at doi: 10.12669/pjms.36.COVID19S4.2785

Al-Saadi, N. (2017). E-learning and its impact on future generations. Journal of Information Technology Education: Research, 17, 187-160. Retrieved from http://www.informingscience.com/Publications/3524

Piaget, J. (1971) Psychology and Epistemology: Towards a Theory of Knowledge. New York: Grossman

Rahmat, N. H., Mok, S. S., Lau, S. K., Ling, T. S. (2021) An Investigation of How Online Learning reduces ZPD in Mandarin Language Classroom. International Journal of Education, Vol 13(1), pp 1-15. Retrieved from https://doi.org/10.5296/ije.v13i1.18399

Smart, K. L., \& Cappel, J. J. (2006). Students' Perceptions of Online Learning: A Comparative Study. Journal of Information Technology Education. 5: 201-219. https://eric.ed.gov/?id=EJ808946

Vonderwell, S., Zachariah S. (2005). Factor that Influence Participation in Online Learning. Journal of Research on Technology in Education. Vo. 38.No.2, p 213-230. https://doi.org/10.1080/15391523.2005.10782457 